\title{
ENVIRONMENTAL STRATIFICATION IN THE BRAZILIAN CERRADO ON THE YIELD AND FIBER QUALITY OF COTTON GENOTYPES
}

\author{
ESTRATIFICAÇÃO AMBIENTAL NO CERRADO BRASILEIRO SOBRE O \\ RENDIMENTO E A QUALIDADE DA FIBRA DOS GENÓTIPOS DE ALGODÃO
}
Mayara Fávero COTRIM'; Francisco José Correa FARIAS²; Luiz Paulo de CARVALHO²; Larissa Pereira Ribeiro TEODORO'룬 Leonardo Lopes BHERING ${ }^{3}$; Paulo Eduardo TEODORO ${ }^{1 *}$

1. Universidade Federal de Mato Grosso do Sul, Campus de Chapadão do Sul, Chapadão do Sul, MS, Brasil; 2. Embrapa Algodão, Campina Grande, PB, Brasil; ${ }^{3}$ Universidade Federal de Viçosa, Departamento de Biologia Geral. eduteodoro@hotmail.com

\begin{abstract}
Environmental stratification studies are important for the plant breeding, since they allow to adequately plan the experimental network. The objective of this work was to identify similar environments for cotton cultivation in the Brazilian Cerrado regarding yield and fiber quality. Nineteen field studies were carried out in a randomized complete block design with twelve genotypes and four replicates. Agronomic (cotton seed yield and fiber percentage) and technological traits (length, micronaire, fiber strength) were evaluated. These results indicate that there are six environments (PVA3, MON, SHE1, SIN, PPA e TRIN) in which the cotton trials should be installed as a matter of priority owing to the phenotypic response pattern obtained for the evaluated traits. The remaining 13 environments are similar to each other for all traits and can be summarized in strategic locations depending on the ease of installation of the trials.
\end{abstract}

KEYWORDS: Gossypium hirsutum. Genotypes x environments interaction. Fiber quality.

\section{INTRODUCTION}

The development and release of cotton cultivars in Brazil follows growers demands for competitive fiber yield, and fulfill industrial textile requirements in the Cerrado environment, the largest cotton growing area in Brazil (MORELLO et al., 2010, MORELLO et al., 2012; MORELLO et al., 2015). Before cultivar recommendation, multiple assays are performed to evaluate genotypes in different environments. The differential behavior of a genotype for a given trait as a function of environmental variation is defined as genotype $\mathrm{x}$ environment (GxE) interaction. Thus, investigating the $\mathrm{GxE}$ interaction is essential for accurate recommendation of the best genotypes for a given region.

For this, the breeders perform several trials in the final stages of breeding programs. Regarding this, Embrapa Algodão divided its experimental network into two large regions from Brazil: Cerrado and Semi-Arid, where most cotton cultivation is concentrated in the Cerrado, acording data from Conab (2017). This biome occupies about $22 \%$ of the Brazilian territory territory and has peculiar edaphoclimatic characteristics along its extension in terms of rainfall, temperature, relative air humidity, as well as different types of soil.

Recently, in this biome has been highlighted an important growing modality denominated off- season coton, characterized by the sowing of the cotton after the harvest of a previous growing in rainfed system (FREIRE, 2015). This practice has been carried out by farmers in the Mid-West region after the soybean harvest, sown in early October. This fact also contributes to the GxE interaction observed among the sites located in the Cerrado, since the climatic conditions of the off-season are different from those found in the traditional growing season.

In this sense, valuable information for breeding programs concerns environmental stratification. It is important to identify similarity in the pattern of response of genotypes throughout the experimental network. Lin (1982) proposed an algorithm to estimate the sum of squares of the GxE interaction and to cluster environments whose interaction is not significant. In addition to facilitating the recommendation of the best genotypes, this procedure makes it possible to evaluate the representativeness of the network and allows the breeder to make decisions regarding the disposal of environments, aiming at minimizing the cost with the trials.

Another way of identifying environments is through the phenotypic correlation between environments. Environments whose genotypes have similar performance have high magnitude correlations. The representation of these estimates can be made through the correlation network. This 
analysis has already been used efficiently to characterize complex systems in many areas, such as biology (URSEM et al., 2008; DILEO et al., 2011; PEARCE et al., 2015), public health (SABA et al., 2014) and food science (Monforte et al. 2015). However, there are no studies using the correlation network for environmental stratification in plant breeding.

Silva Filho et al. (2017) evaluated the environmental stratification of cotton genotypes for cotton seed yield. However, environmental stratification studies of traits related to fiber quality do not yet exist. Therefore, the objective of this study was to identify similar environments for cotton growing in the Brazilian Cerrado regarding yield and quality fiber.

\section{MATERIAL AND METHODS}

Nineteen trials of cotton cultivars were conducted in the 2013/2014 and 2014/2015 harvests (years). The environments were constituted by the combinations between locations and years, according to edaphoclimatic characteristics (Table 1) and graphic representation of locations. The cultivars used as standards were: (TMG $41 \mathrm{WS}$, TMG 43 WS, IMA CV 690, IMA 5675 B2RF, IMA 08 WS, NUOPAL, DP 555 BGRR, DELTA OPAL, BRS 286, BRS 335, BRS 368 RF and BRS 369 RF). The cultivars were not the same in all years and locations. The selection was based on the criterion of participation in the largest number of experiments, to reduce the imbalance of the analysis of variance.

Table 1. Locations and geographic coordinates as altitude (ALT), latitude (LAT), longitude (LONG), rain fall (RF), average annual temperature (TEMP) in the 2013/2014 and 2014/2015 harvests.

\begin{tabular}{|c|c|c|c|c|c|c|c|c|}
\hline Location/State & Initials ${ }^{1}$ & Harvest & $\begin{array}{l}\text { Alt. } \\
\text { (m) }\end{array}$ & $\begin{array}{l}\text { Lat. } \\
\text { (S) }\end{array}$ & Long. (W) & $\begin{array}{l}\text { RF. } \\
(\mathrm{mm})\end{array}$ & $\begin{array}{l}\text { Temp. } \\
\left({ }^{\circ} \mathrm{C}\right)\end{array}$ & Climate $^{2}$ \\
\hline Trindade/MG & TRI & 2013/2014 & 927 & $21^{\circ} 06^{\prime}$ & $44^{\circ} 10^{\prime}$ & 1467 & 23.2 & Aw \\
\hline $\begin{array}{l}\text { Santa Helena do } \\
\text { Goias/GO }\end{array}$ & $\begin{array}{l}\text { SHE1 } \\
\text { SHE2 }\end{array}$ & $\begin{array}{l}2013 / 2014 \\
2014 / 2015\end{array}$ & 562 & $17^{\circ} 48^{\prime}$ & $50^{\circ} 35^{\prime}$ & 1539 & 24.3 & Aw \\
\hline Pedra Preta/MT & $\begin{array}{l}\text { PPA1 } \\
\text { PPA2 } \\
\text { PVA1 }\end{array}$ & $\begin{array}{l}2013 / 2014 \\
2014 / 2015 \\
2013 / 2014\end{array}$ & 248 & $16^{\circ} 37^{\prime}$ & $54^{\circ} 28^{\prime}$ & 489 & 25,1 & Bsh \\
\hline $\begin{array}{l}\text { Primavera do } \\
\text { leste/MT }\end{array}$ & $\begin{array}{l}\text { PVA2 } \\
\text { PVA3 } \\
\text { PVA4 }\end{array}$ & $\begin{array}{l}2013 / 2014 \\
2014 / 2015 \\
2014 / 2015\end{array}$ & 465 & $15^{\circ} 33^{\prime}$ & $54^{\circ} 17^{\prime}$ & 1784 & 22,0 & Aw \\
\hline Campo Verde/MT & $\begin{array}{l}\text { CV1 } \\
\text { CV2 }\end{array}$ & $\begin{array}{l}2013 / 2014 \\
2014 / 2015\end{array}$ & 736 & $15^{\circ} 32^{\prime}$ & $55^{\circ} 10^{\prime}$ & 1902 & 26.3 & Af \\
\hline Sinop/MT & SIN & $2013 / 2014$ & 345 & $11^{\circ} 51^{\prime}$ & $55^{\circ} 30^{\prime}$ & 1818 & 25.0 & Aw \\
\hline $\begin{array}{l}\text { Luiz Eduardo } \\
\text { Magalhães/BA }\end{array}$ & LEM & $2013 / 2014$ & 769 & $12^{\circ} 5^{\prime}$ & $45^{\circ} 47^{\prime}$ & 1511 & 24.2 & Aw \\
\hline São Desidério/BA & SDES & $2013 / 2014$ & 497 & $12^{\circ} 21^{\prime}$ & $44^{\circ} 58^{\prime}$ & 1289 & 24.7 & Aw \\
\hline Montividiu/GO & MON & $2013 / 2014$ & 821 & $17^{\circ} 26^{\prime}$ & $51^{\circ} 10^{\prime}$ & 1512 & 23.0 & Aw \\
\hline $\begin{array}{ll}\text { Magalhães } & \text { de } \\
\text { Almeida/MA } & \end{array}$ & MAG & $2013 / 2014$ & 36 & $03^{\circ} 23^{\prime}$ & $42^{\circ} 12^{\prime}$ & 1430 & 27.2 & Aw \\
\hline Teresina/PI & TER & $2013 / 2014$ & 72 & $05^{\circ} 05^{\prime}$ & $42^{\circ} 48^{\prime}$ & 1349 & 27.6 & Aw \\
\hline $\begin{array}{l}\text { Chapadão } \\
\text { Sul/MS }\end{array}$ & CHA & $2014 / 2015$ & 810 & $18^{\circ} 47^{\prime}$ & $52^{\circ} 37^{\prime}$ & 1600 & 22.7 & Aw \\
\hline Sorriso/MT & SOR & $2014 / 2015$ & 365 & $12^{\circ} 32^{\prime}$ & $55^{\circ} 42^{\prime}$ & 1883 & 25.0 & Aw \\
\hline
\end{tabular}

${ }^{1}$ : abbreviations of locations. ${ }^{2}$ : Köppen classification.

The experimental design used in each trial was a randomized complete block with 12 treatments and four replicates. Experimental unit consisted of four rows of $5 \mathrm{~m}$ in length, spaced at $0.90 \mathrm{~m}$ between rows with a density of $9 \mathrm{~m}^{-1}$ plants. In each experimental unit, cotton seed yield was evaluated in the two central lines, being corrected for $13 \%$ moisture and extrapolated to $\mathrm{kg} \mathrm{ha}^{-1}$ by covariance method.
The joint analysis of variance considered effect of genotypes (G) as fixed and effects of environments $(\mathrm{E})$ and genotypes $\mathrm{x}$ environments $(\mathrm{G}$ $\mathrm{x} E$ ) as random. The environments were stratified by Lin (1982) traditional method and the clusters were constituted by genotypes whose mean squares values of the $\mathrm{G} \times \mathrm{E}$ interaction were not significant. The $\mathrm{F}$ test estimated the probability of forming groups using the Genes software (CRUZ, 2013). 
The graphical expression was performed by the functional relationship between the estimates of the correlation coefficients between the environments using the correlations network, performed by Rbio software (BHERING, 2017), in which the proximity between nodes (traces) is proportional to the total correlation value between these (FRUCHTERMAN; REINGOLD, 1991) using package "qgraph". The thickness of the edges was controlled by applying the cut-off value equal 0.60 , wherein only $\left|\mathrm{r}_{\mathrm{ij}}\right| \geq 0.60$ have their edges highlighted. Thus, positive correlations were highlighted in green, while negatives in red.

\section{RESULTS AND DISCUSSION}

The effect of genotypes was significant for all traits evaluated (Table 2), except cotton seed yield (YIELD). This is explained by the environment effects magnitude and GxE interaction, which consumed the variability among the genotypes for this trait (CRUZ et al., 2012). For the effects of environment and $\mathrm{G} \times \mathrm{E}$ interaction the traits were significant. Therefore, the data presented here has credibility for the study on environmental stratification in agronomic and technological traits of cotton.

Table 2. Summary of the joint analysis of variance for the agronomic traits cotton seed yield (YIELD) and fiber percentage (FP) and technological variables micronaire (MIC), fiber length (FL) and fiber strength (FS) evaluated in 12 early cotton genotypes in 19 trials in Brazilian Cerrado in the 2013/2014 e 2014/2015 harvest.

\begin{tabular}{|c|c|c|c|c|c|c|}
\hline Variation sources & DF & YIELD & FP & MIC & FL & FS \\
\hline Block/Enviroment & 54 & 582221.44 & 4.32 & 0.13 & 0.73 & 2.91 \\
\hline Genotype (G) & 11 & $1310128.57^{\mathrm{ns}}$ & $136.68 * *$ & $1.86^{* *}$ & $23.79 * *$ & $79.78 * *$ \\
\hline Enviroment (E) & 18 & $61511492.56^{* *}$ & $104.32 * *$ & $5.00 * *$ & $35.18^{* *}$ & $88.02 * *$ \\
\hline GxE & 198 & $874829.53 * *$ & $7.84 * *$ & $0.13 * *$ & $1.06^{* *}$ & $3.76 * *$ \\
\hline Error & 627 & 333939.13 & 2.51 & 0.06 & 0.58 & $2.33 * *$ \\
\hline $\mathrm{CV}(\%)$ & & 13.88 & 3.77 & 5.77 & 2.55 & 5.04 \\
\hline
\end{tabular}

The presence of significant GxE interaction can be attributed to predictable factors such as: soil management, pest and disease, additional irrigation, basis fertilizer and other; and unpredictable: rainfall, temperature, air humidity and radiation throughout the crop cycle, among others. Similar results were verified by other authors when studying the $G \times E$ interaction in cotton in localities in Brazil (SOUZA et al., 2006; SUINAGA et al., 2006; SILVA FILHO et al., 2008; FARIAs et al., 2016).

The coefficient of variation estimates obtained in the joint ANOVA show good experimental accuracy according to the PimentelGomes (2015) and are inferior to other works related to the competition cotton genotypes (BLANCHE; MYERS 2006; BAXEVANOS et al., 2008; NG et al., 2013; NAI-YIN et al., 2013; FARIAs et al., 2016).

By forming groups of localities with nonsignificant interaction due to the YIELD (Table 3), the environments MAG, TER, SIN, CV1, LEM, PVA2, SOR, CHA, CV2 and PPA2 demonstrated similarity among themselves. MON and PVA3 presented different behavior in relation to the other environments. Considering that each localities and year characterize a different environment, it can be assumed that YIELD was affected by changes in the environment. In addition, there are fluctuations in altitude, latitude and longitude in the main cotton producing regions of Brazil. These peculiar features of the country reinforce the importance of environmental stratification studies for the main agricultural crops, such as cotton.

These results indicate that it is important to evaluate the YIELD in MON and PVA3, these environments have edaphoclimatic characteristics that provided different behavior of the genotypes. The clustering of the other clustered environments demonstrates the possibility of reducing the Cerrado experimental network, allowing the Embrapa breeding program to optimize its financial resources.

For FP, localities that did not demonstrate similarity were SHE1, SIN, MON and PVA3; the others formed a group with non-significant $\mathrm{GxE}$ interaction. The PPA1 environment had no similarity pattern with no other environment for the MIC trait. Similar fact occurred for FL, where PVA3 was the only environment that did not cluster with the other environments. For the FS trait, TRIN, SIN and PVA3 environments were isolated and showed no similarity. 
Environmental stratification in the Brazilian...

COTRIN, M. F. et al

Table 3. Clustering of cotton cultivar for cotton seed yield (YIELD) and fiber percentage (FP) and technological variables micronaire (MIC), fiber length (FL) and fiber strength (FS) based on the non-significant $\mathrm{G} \times \mathrm{E}$ interaction, according to Lin (1982), in 19 environments and 12 genotypes.

\begin{tabular}{|c|c|c|c|c|}
\hline Trait & Similar Environments & ${ }^{1}$ Fcal & Ftab & Non-similar environments \\
\hline YIELD & $\begin{array}{l}\text { MAG, TER, SIN, CV1, LEM, PVA2 } \\
\text { SOR, CHA, CV2 and PPA2 }\end{array}$ & 1.18 & 1.27 & PVA3 and MON \\
\hline FP & $\begin{array}{l}\text { MAG, CHA, PVA1, PVA2, PVA4, LEM, SDES, } \\
\text { CV1, CV2, PPA1, PPA2, TRIN, SHE2, SOR and } \\
\text { TER }\end{array}$ & 0.91 & 1.21 & $\begin{array}{l}\text { SHE1, SIN, MON and } \\
\text { PVA3 }\end{array}$ \\
\hline MIC & $\begin{array}{l}\text { SDES, CHA, TRIN, LEM, SHE1, SHE2, PPA2, } \\
\text { PVA1, PVA2, PVA4, CV1 and CV2 }\end{array}$ & 1.19 & 1.24 & PPA1 \\
\hline $\mathrm{FL}$ & $\begin{array}{l}\text { CV1, CV2, SHE1, TRIN, PPA1, PPA2, SDES, } \\
\text { SIN, LEM, SHE2, SOR, PVA1, PVA2, PVA4, } \\
\text { CHA and MAG }\end{array}$ & 1.18 & 1.21 & PVA3 \\
\hline FS & $\begin{array}{l}\text { CV1, CV2, PPA1, PPA2, CHA, SHE2, SHE1, } \\
\text { PVA1, PVA4, MAG, TER, SDES, PVA2, SOR } \\
\text { and MON }\end{array}$ & 1.14 & 1.21 & TRIN, SIN and PVA3 \\
\hline
\end{tabular}

${ }^{1}$ Fcal: calculated $\mathrm{F}$ value; Ftab: tabulated $\mathrm{F}$ value at $5 \%$ probability.

In the correlation network analysis, the environments were represented by nodes, which are connected by traces. Each end contains a thickness that indicates the correlation magnitude (weak, moderate or strong). Figure $1 \mathrm{~A}$ demonstrates the phenotypic correlations network for the YIELD. It is possible to observe that the correlations were positive and of high magnitude $(>0.70)$ only for the SHE2, SHE1, SDE and PPA1 environments; and moderate in SHE1, TRI and TER, MAG. These results demonstrate that identifying redundant localities for this trait is harder.
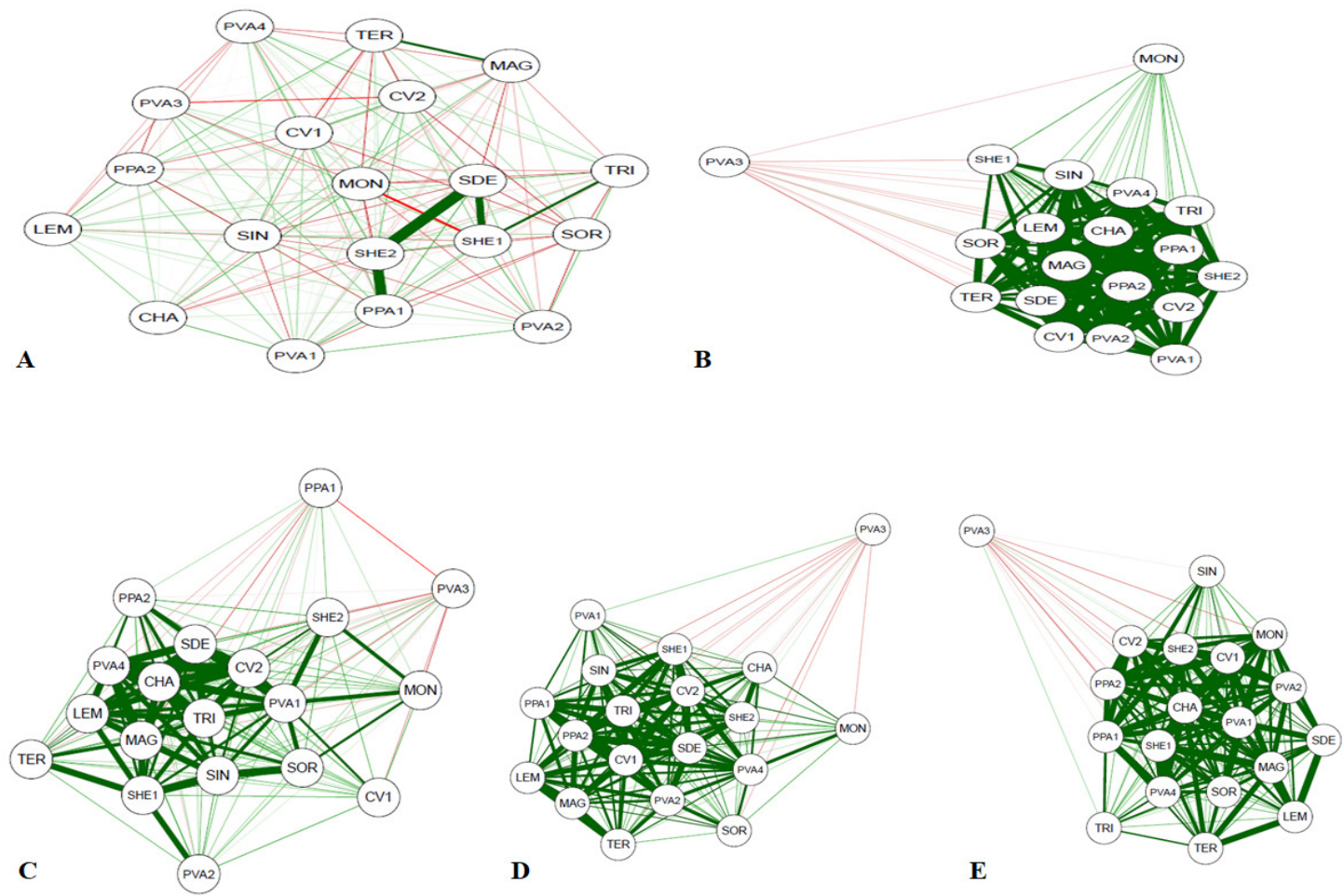

Figure 1. Phenotypic correlations network among the environments (Table 1) for cotton seed yield (A) and fiber percentage (B) and technological variables micronaire (C), fiber length (D) and fiber strength (E). Positive correlations are highlighted in green and negative in red, where the thickness of the traces indicates the strength of the correlation. 
For FP (Figure 1B), all environments, except PVA3 and MON, showed a positive strong magnitude correlation $(>0.70)$. The PVA3 environment presented negative correlation and MON positive correlation, both of weak magnitude. For MIC, the PVA3 environment also showed negative correlation of weak magnitude (Figure 1C), as well as PPA1. Corroborating with the other traits, for FL and FS, the PVA3 environment also confirmed negative and positive correlation of weak magnitude (Figure 1D and 1E).

It is important to note that PVA3 showed differences in four of the five analyzed variables. This result points out the need for the genotypes to be evaluated in this environment in future research. Similarly, the MON, SHE1, SIN, PPA and TRIN environments did not present similarity pattern with the other environments in at least one of the evaluated traits. These results indicate that there are six environments (PVA3, MON, SHE1, SIN, PPA and TRIN) in which cotton trials should be prioritized because of the phenotypic response pattern obtained for the traits evaluated. The remaining 13 environments are similar to each other for all trait and can be summarized in strategic locations depending on the ease of installation of the trials.

However, it is important to emphasize that owing to exclusion, it is advisable to have information on a larger number of crops, agroclimatic characteristics of the environments with similar altitudes, latitude and climate, coinciding with the established agroclimatic zoning for the cotton crop.

\section{CONCLUSIONS}

There are six environments (PVA3, MON, SHE1, SIN, PPA1, PPA2 e TRIN) in which the cotton trials should be installed as a matter of priority owing to the phenotypic response pattern obtained for the evaluated traits.

The remaining 13 environments are similar to each other for all traits and can be summarized in strategic locations depending on the ease of installation of the trials.

RESUMO: Os estudos de estratificação ambiental são importantes para a criação de plantas, uma vez que permitem planejar adequadamente a rede experimental. $\mathrm{O}$ objetivo deste trabalho foi identificar ambientes similares para cultivo de algodão no Cerrado brasileiro quanto a produtividade e qualidade da fibra. Dezenove experimentos foram realizados em um delineamento de blocos ao acaso com doze genótipos e quatro repetições. Foram avaliados caracteres agronômicos (produtividade de algodão em caroço e porcentagem de fibra) e tecnológicas (comprimento, micronaire, resistência de fibras). Os resultados indicam que existem seis ambientes (PVA3, MON, SHE1, SIN, PPA e TRIN) em que os ensaios de algodão devem ser instalados como prioritários devido ao padrão de resposta fenotípica obtido para os traços avaliados. Os 13 ambientes restantes são semelhantes entre si para todos os caracteres e podem ser resumidos em locais estratégicos, de acordo com a facilidade de instalação dos ensaios.

PALAVRAS-CHAVE: Gossypium hirsutum. Interação genótipos x ambientes. Qualidade da fibra.

\section{REFERENCES}

BHERING, L. L. Rbio: a tool for biometric and statistical analysis using their platform. Crop Breeding and Applied Biotechnology, Viçosa, v. 17, p. 187-190, 2017. https://doi.org/10.1590/1984-70332017v17n2s29

BAXEVANOS, D.; GOULAS, C.; ROSSI, J.; BRAOJOS, E. Separation of cotton cultivar testing sites based on representativeness and discriminating ability using GGE biplots. Agronomy Journal, Madson, v. 100, p. 1230-1236, 2008. https://doi.org/10.2134/agronj2007.0363

BLANCHE, S. B.; MYERS, G. O. Identifying discriminating locations for cultivar selection in Louisiana. Crop Science, Madson, v. 46, p. 946-949, 2006. https://doi.org/10.2135/cropsci2005.0279

Companhia Nacional de Abastecimento - CONAB. Acompanhamento de Safra Brasileira: grãos, décimo segundo levantamento, Agosto, 2015. Available at [http://www.conab.gov.br]. Accessed Agosto 10, 2017. 
CRUZ, C. D. GENES a software package for analysis in experimental statistics and quantitative genetics. Acta Scientiarum Agronomy, Maringá, v. 35, p. 271-276, 2013. https://doi.org/10.4025/actasciagron.v35i3.21251

CRUZ, C. D.; REGAZZI, A. J.; CARNEIRO, A. J.; SOUZA, P. C. Modelos biométricos aplicados ao melhoramento genético. Viçosa: Editora UFV, 2012.

DILEO, M. V.; STRAHAN, G. D.; BAKKER, M. D.; HOEKENGA, O. A. Weighted correlation network analysis (WGCNA) applied to the tomato fruit metabolome. Plos one, New York, 26683, 2011. https://doi.org/10.1371/journal.pone.0026683

FARIAS, F. J. C.; CARVALHO, L. P.; SILVA FILHO, J. L.; TEODORO, P. E. Biplot analysis of phenotypic stability in upland cotton genotypes in Mato Grosso. Genetics and Molecular Research, Ribeirão Preto, v. 15, gmr.15038009, 2016a. https://doi.org/10.4238/gmr.15028009

FARIAS, F. J. C.; CARVALHO, L. P.; SILVA FILHO, J. L.; TEODORO, P. E. Correlations and path analysis among agronomic and technological traits of upland cotton. Genetics and Molecular Research, Ribeirão Preto, v. 15, gmr.15038239, 2016b. https://doi.org/10.4238/gmr.15038239

FREIRE, E. C. F. Algodão no cerrado do Brasil. Brasília: ABRAPA, 2015.

FRUCHTERMAN, T. M.; REINGOLD, E. M. Graph drawing by force-directed placement. Software: Practice and experience, New York, v. 21, p. 1129-1164, 1991. https://doi.org/10.1002/spe.4380211102

LIN, C. S. Grouping genotypes by a cluster method directly related to genotype-environment interaction meansquare. Theoretical and Applied Genetics, Amsterdã, v. 62, p. 277-280, 1992.

https://doi.org/10.1007/BF00276251

MONFORTE, A. R.; JACOBSON, D.; FERREIRA, A. C. S. Chemiomics: network reconstruction and kinetics of Port wine aging. Journal of Agricultural and Food Chemistry, Amsterdã, v. 63, p. 2576-2581, 2015. https://doi.org/10.1021/jf5055084

MORELLO, C. L.; PEDROSA, M. B.; SUASSUNA, N. D.; LAMAS, F. M.; CHITARRA, L. G.; SILVA, J. L.; ANDRADE, F. P.; BARROSO, P. A. V.; RIBEIRO, J. L.; GODINHO, V. P. C.; LANZA, M. A. BRS 336: a high-quality fiber upland cotton cultivar for Brazilian savanna and semi-arid conditions. Crop Breeding and Applied Biotechnology, Viçosa, v. 12, p. 92-95, 2012. https://doi.org/10.1590/S1984-70332012000100012

MORELLO, C. L.; SUASSUNA, N. D.; BARROSO, P. A. V.; SILVA FILHO, J. L.; FERREIRA, A. C. B.; LAMAS, F. M.; PEDROSA, M. B.; CHITARRA, L. G.; RIBEIRO, J. L.; GODINHO, V. P. C.; LANZA, M. A. BRS 369RF and BRS 370RF: Glyphosate tolerant, high-yielding upland cotton cultivars for central Brazilian savanna. Crop Breeding and Applied Biotechnology, Viçosa, v. 15, p. 290-294, 2015. https://doi.org/10.1590/1984-70332015v15n4c49

MORELLO, C. L.; SUASSUNA, N. D.; FARIAS, F. J. C.; LAMAS, F. M.; PEDROSA, M. B.; RIBEIRO, J. L.; GODINHO, V. P. C. FREIRE, E. C. BRS 293: A midseason highyielding upland cotton cultivar for Brazilian savanna. Crop Breeding and Applied Biotechnology, Viçosa, v. 10, p. 180-182, 2010. https://doi.org/10.12702/1984-7033.v10n02a13

NAI-YIN, X.; MICHEL, F.; GUO-WE, Z.; JIAN, L. A.; ZHI-GUO, Z. The Application of GGE biplot analysis for evaluating test locations and mega-environment investigation of cotton regional trials. Journal of Integrative Agriculture, New Deli, v. 13, p. 60-65, 2013.

PEARCE S, FERGUSON A, KING J AND WILSON ZA (2015) Flower Net: a gene expression correlation network for anther and pollen development. Plant Physiology 167: 1717-1730.

https://doi.org/10.1104/pp.114.253807 
PIMENTEL-GOMES, F. Curso de estatística experimental. Piracicaba: ESALQ, 2015.

R DEVELOPMENT CORE TEAM. R: a language and environment for statistical computing. Vienna: $\mathrm{R}$ Foundation for Statistical Computing. Disponível em <http://www.R- project.org $>$.

SABA, H.; VALE, V. C.; MORET, M. A.; MIRANDA, J. G. V. Spatio temporal correlation networks of dengue in the state of Bahia. BMC Public Health, New York, v. 14, p. 1085, 2014.

https://doi.org/10.1186/1471-2458-14-1085

SILVA FILHO, J. L.; MORELLO, C. L.; FARIAS, F. J. C.; LAMAS, F. M.; PEDROSA, M. E. RIBEIRO, J. L. Comparação de métodos para avaliar a adaptabilidade e estabilidade produtiva em algodoeiro. Pesquisa Agropecuária Brasileira, Brasília, v. 43, p. 349-355, 2008. https://doi.org/10.1590/S0100-

204X2008000300009

SILVA FILHO JL, MORELLO CL, SUASSUNA ND, FARIAS FJC, LAMAS FM, PEDROSA MB, RIBEIRO JL AND SUASSUNA TMF (2017) Environmental stratification in cotton in the presence or absence of genotypes with high ecovalence. Crop Breeding and Applied Biotechnology 17: 32-39.

https://doi.org/10.1590/1984-70332017v17n1a5

SOUZA, A. A.; FREIRE, E. C.; BRUNO, R. L. A.; CARVALHO, L. P.; SILVA FILHO, J. L.; PEREIRA, W. E. Estabilidade e adaptabilidade do algodoeiro herbáceo no Cerrado do Mato Grosso e Mato Grosso do Sul. Pesquisa Agropecuária Brasileira, Brasília, v. 41, p. 1125-1131, 2006. https://doi.org/10.1590/S0100204X2006000700008

SUINAGA, F., A.; BASTOS, C. S.; PACIFICI, L. E. R. Phenotypic adaptability and stability of cotton cultivars in Mato Grosso State, Brazil. Pesquisa Agropecuária Tropical, Goiânia, v. 36, p. 145-150, 2006.

URSEM, R.; TIKUNOV, Y. BOVY, A.; BERLOO, R. VAN; EEUWIJK, F. VAN. A correlation network approach to metabolic data analysis for tomato fruits. Euphytica, Dordrecht, v. 161, p. 181-193, 2008. https://doi.org/10.1007/s10681-008-9672-y 